\title{
A review of the currently recognised zoogonid cercariae, including the identification and emergence ecology of Cercaria capricornia XI (Digenea: Zoogonidae) from Nassarius olivaceus (Gastropoda: Nassariidae) in Central Queensland, Australia
}

\author{
Leonie J. Barnett ${ }^{1}$, Terrence L. Miller ${ }^{2}$ and Thomas H. Cribb ${ }^{3}$ \\ ${ }^{1}$ Central Queensland University, Academic Learning Services Unit, Bruce Highway, North Rockhampton, Queensland, Australia; \\ ${ }^{2}$ School of Marine and Tropical Biology, James Cook University, Cairns, Queensland, Australia; \\ ${ }^{3}$ School of Biological Sciences, The University of Queensland, Brisbane, Queensland, Australia
}

\begin{abstract}
In the present study, we review the known zoogonid cercariae, summarise their life-cycles and first intermediate host distributions, and present a new cercaria, Cercaria capricornia XI (Digenea: Zoogonidae), which was found in one of three nassariid gastropods, Nassarius olivaceus (Bruguière), surveyed in the intertidal zone in the Capricornia region of Central Queensland, Australia. Morphological data and molecular analysis of the ITS2 rDNA region support placement of this cercaria in the family Zoogonidae but do not allow any further resolution of its identity. There are now fifteen cercariae described as belonging to the Zoogonidae; thirteen of these, including the present species, infect neogastropods as first intermediate hosts and two use vetigastropods. This study reinforces the pattern that the Nassariidae is by far the most commonly reported family for the Zoogonidae. Given its richness we predict that the Nassariidae will prove to harbour many more zoogonid species.
\end{abstract}

Keywords: Capricornia, ITS2, Trematoda, internal transcribed spacer 2, Platyhelminthes

The Zoogonidae Odhner, 1902 is a family containing parasites of teleosts and occasionally elasmobranchs (Bray 1986, 1987, 2008). The asexual stages use gastropods as first intermediate hosts and a wide range of invertebrates as second intermediate hosts, frequently polychaetes and echinoderms, but also gastropods (Bray 1986, Jangoux 1987). Known cercariae of this family typically have the form of a cercariaeum (tail-less). Madhavi and Shameem (1991) published a list of reported zoogonid cercariae and their hosts when they described Cercaria chilkaensis II Madhavi et Shameem, 1991 from Nassarius orissaensis (Preston) in India. The taxonomic history of zoogonid cercariae is confused; there are currently many synonymous names recognised and there have been numerous revisions of descriptions. All zoogonid cercariae reported to date, with the exception of Cercaria crispata Pelseneer, 1906, Cercaria giardi Pelseneer, 1906 and Cercaria zoogonides Chubrik, 1966, have been described with a stylet (Pelseneer 1906, Chubrik 1966, Bray 1986, Abdul-Salam and Sreelatha 1998).

Three marine gastropods Nassarius dorsatus (Röding), Nassarius olivaceus (Bruguière) and Nassarius pullus (Linnaeus) are common scavengers in the intertidal mangroves of the Capricornia region of Central Queensland,
Australia. The aims of the present study were to identify and characterise the ecology of cercariae infecting these three gastropods in this region. During the survey, a single infection with a zoogonid-like cercaria lacking a stylet was found in $N$. olivaceus. This cercaria is characterised using morphological and genetic analyses, namely Bayesian inference analysis of the internal transcribed spacer 2 (ITS2) ribosomal DNA (rDNA) region.

\section{MATERIALS AND METHODS}

\section{Host gastropod and parasite collection}

Gastropods were collected by hand from mudflats at Sandy Point, Corio Bay $\left(22^{\circ} 58^{\prime} \mathrm{S}\right.$; $\left.150^{\circ} 46^{\prime} \mathrm{E}\right)$, Ross Creek, Yeppoon $\left(23^{\circ} 8^{\prime} \mathrm{S} ; 150^{\circ} 45^{\prime} \mathrm{E}\right)$ and the mouth of Cawarral Creek, Keppel Sands $\left(23^{\circ} 19^{\prime} \mathrm{S}\right.$; $\left.150^{\circ} 47^{\prime} \mathrm{E}\right)$ in Central Queensland, Australia. Totals of 1766 Nassarius dorsatus, 1908 N. olivaceus and 1614 N. pullus were collected between August 2004 and May 2006. Gastropods were held in filtered seawater at room temperature $\left(20-28^{\circ} \mathrm{C}\right)$ and examined for naturally emerged cercariae every 1-3 days for up to one month. Freshly emerged cercariae were transferred to a cavity block in a small volume of seawater and heat-killed by pouring several volumes of near boiling seawater into the dish. Specimens for morphological analysis were fixed in 5\% formalin and specimens for molecular analysis were stored in $70 \%$ ethanol. The infected gastropod was then dissect- 
Table 1. List of taxa and ITS2 sequences used for phylogenetic analysis.

\begin{tabular}{|c|c|c|}
\hline Species & Host/locality (where given) & GenBank Acc. Nos. \\
\hline \multicolumn{3}{|l|}{ Zoogonidae } \\
\hline Cercaria capricornia $\mathrm{XI}$ & Nassarius olivaceus, Capricornia, Australia & KJ188132 \\
\hline Deretrema nahaense Yamaguti, 1942 & Thalassoma jansenii & KJ188135 \\
\hline Diphterostomum Type F & Pseudocaranx dentex & KJ188134 \\
\hline Steganoderma gibsoni Cribb, Bray et Barker, 1992 & Abudefduf whitleyi & KJ188133 \\
\hline Zoogonus rubellus (Olsson, 1868) & Diplodus sargus & AJ241804 \\
\hline \multicolumn{3}{|l|}{ Haematoloechidae } \\
\hline Haematoloechus breviplexus Stafford, 1902 & Rana catesbeiana, Cochise County, USA & AF387796 \\
\hline \multicolumn{3}{|l|}{ Microphallidae } \\
\hline Maritrema eroliae Yamaguti, 1939 & Clypeomorus bifasciatus, Kuwait & HQ650132 \\
\hline Probolocoryphe uca (Sarkisian, 1957) & Cerithidea cingulate, Kuwait & GQ377842 \\
\hline \multicolumn{3}{|l|}{ Opecoelidae } \\
\hline Cainocreadium labracis (Dujardin, 1845) & Dentex dentex & AJ241795 \\
\hline Macvicaria mormyri (Stossich, 1885) & Lithognathus mormyrus & AJ241802 \\
\hline Nicolla elongata Maillard, 1970 & Phycis phycis & AJ241792 \\
\hline Opecoeloides furcatus (Bremser in Rudolphi, 1819) & Mullus surmuletus & AJ241790 \\
\hline Pachycreadium carnosum (Rudolphi, 1819) & Dentex dentex & AJ241799 \\
\hline Podocotyle scorpaenae (Rudolphi, 1919) & Scorpaena scrofa & AJ241794 \\
\hline Poracanthium furcatum Dollfus, 1948 & Mullus surmuletus & AJ241791 \\
\hline \multicolumn{3}{|l|}{ Paragonimidae } \\
\hline Paragonimus westermani (Kerbert, 1878) & freshwater crab, north-east India & DQ351845 \\
\hline Paragonimus heterotremus Chen et Hsia, 1964 & Larnaudia larnaudii, Saraburi, Thailand & AB354221 \\
\hline \multicolumn{3}{|l|}{ Plagiorchiidae } \\
\hline Aptorchis aequalis Nicoll, 1914 & Emydura krefftii, Australia & EF014729 \\
\hline Aptorchis megacetabulus Tkach et Snyder, 2007 & Chelodina rugosa, Australia & EF014730 \\
\hline Plagiorchis elegans (Rudolphi, 1802) & not stated & AF151952 \\
\hline Plagiorchis muelleri Tkach et Sharpilo, 1990 & Eptesicus serotinus, Nizhin, Ukraine & AF151947 \\
\hline
\end{tabular}

ed to determine the nature of intramolluscan stages. Sporocysts were placed into near boiling seawater and fixed in $5 \%$ formalin or $70 \%$ ethanol. Whole mounts and wet specimens are deposited in the Queensland Museum, Brisbane, Queensland, Australia.

\section{Morphological analysis}

Fixed cercariae and sporocysts were examined as temporary wet mounts without flattening. Measurements were taken using an eyepiece micrometer on an Olympus BX-41 microscope and are given in micrometres as the range followed by the mean in parentheses. Drawings were prepared with the aid of a drawing tube.

\section{Confirmation of prevalence}

A subset of putatively uninfected gastropods was dissected to check infection status. Of $720 N$. dorsatus (40.8\% of 1766$), 877$ N. olivaceus $(46.0 \%$ of 1908$)$ and $70 N$. pullus $(4.3 \%$ of 1614$)$ dissected, there were no gastropods infected with a trematode similar to that reported here. This result suggests that the emergence prevalence reported here closely approximates the actual prevalence.

\section{Molecular analysis}

Total genomic DNA was extracted from ethanol-fixed specimens using a QIAGEN $^{\circledR}$ (Doncaster, VIC, USA) DNeasy ${ }^{\circledR}$ Blood and Tissue Kit following the manufacturer's protocol. Final elution volume was $30 \mu 1$. Amplification of the ITS2 region was performed with the primers 3S [5'-GGTACCGGTGGATCACGTGGCTAGTG-3' (Morgan and Blair 1995)] and ITS2.2 [5'-CCTGGTTAGTTTCTTTTCCTCCGC-3' (Cribb et al. 1998)]. PCR amplification (total volume $25 \mu$ l) was performed using 1X iTaq Buffer (Bio-Rad, Hercules, CA, USA), 1.25 U iTaq $^{\text {TM }}$ DNA polymerase (Bio-Rad), $1.5 \mathrm{mM} \mathrm{MgCl}_{2}, 200 \mu \mathrm{M}$ each dNTP, $0.2 \mu \mathrm{M}$ each primer and $1 \mu 1$ genomic extract, with the following thermocycling profile: $5 \mathrm{~min}$ denaturation at $95^{\circ} \mathrm{C} ; 30$ cycles of $30 \mathrm{~s}$ at $95^{\circ} \mathrm{C}, 30 \mathrm{~s}$ at $60^{\circ} \mathrm{C}, 30 \mathrm{~s}$ at $72^{\circ} \mathrm{C}$; and 4 min extension at $72^{\circ} \mathrm{C}$. The PCR amplicon was purified using a QIAGEN QIAquick ${ }^{\circledR}$ PCR Purification Kit (with $30 \mu$ l elution buffer). The purified amplicon was sequenced (in both directions) using the same primers with ABI BigDye ${ }^{\mathrm{TM}}$ v3.1 chemistry at the Australian Genome Research Facility in Brisbane, Queensland. The resulting sequences were edited by eye and the contig constructed manually in MEGA4 (Tamura et al. 2007) from both the forward and reverse sequence and then checked independently using Sequencher ${ }^{\mathrm{TM}}$ version 4.5 (GeneCodes Corp., Ann Arbor, MI, USA). The ITS2 sequence was annotated using HMMer (Eddy 1998) on the ITS2-Database version 3.0.5 (Keller et al. 2009, Koetschan et al. 2010).

\section{Phylogenetic analysis}

The ITS2 rDNA sequence for Cercaria capricornia XI was aligned with those reported for the species of Zoogonidae and the other families listed in Table 1. Although there was only a single zoogonid sequence available from GenBank (Zoogonus rubellus Olsson, 1868), ITS2 data for three zoogonids collected from Australian waters and sequenced using the methods of Lo et al. (2001) were available for comparison. Specimens from the families Haematoloechidae, Microphallidae, Opecoelidae, Plagiorchiidae and Paragonimidae were chosen for comparative purposes (Table 1). No sequences from the closely related family Faustulidae were available for comparison.

The ITS2 dataset was aligned using Muscle version 3.7 (Edgar 2004) on the Cipres Science Gateway (Miller et al. 2009) using the default parameters. The resulting alignment was checked by eye and trimmed to the shortest sequence us- 
ing Mesquite version 2.74 (Maddison and Maddison 2007). This alignment was then exported in NEXUS format and Bayesian inference analysis of the ITS2 dataset was performed using MrBayes version 3.1.2 (Ronquist and Huelsenbeck 2003). The software jModeltest version 0.1.1 (Posada 2008) was used to predict the best substitution model for the ITS2 dataset. Bayesian inference analysis was conducted on the combined dataset using the general time reversible model (GTR) with a gamma distribution $(\mathrm{G})$ of site-specific rates. This was the model most similar to the TVM + G predicted as the best estimator by both the Akaike Information Criterion (AIC) and the Bayesian Information Criterion (BIC) in jModeltest. Bayesian inference analysis was run over 1000000 generations (ngen=1000000) with two runs, each containing four simultaneous Markov Chain Monte Carlo $(\mathrm{MCMC})$ chains (nchains $=4)$ and every $100^{\text {th }}$ tree saved (samplefreq=100). Bayesian analysis used the following parameters: $n s t=6$, rates $=$ gamma, ngammacat $=4$; the MCMC parameters were left at the default settings; and the priors parameters of the combined dataset were set to ratepr=variable. Samples of substitution model parameters, and tree and branch lengths were summarised using the parameters 'sump burnin $=3000$ ' and 'sumt burnin $=3000$ '. These 'burnin' parameters were chosen because the log likelihood scores plateaued before 300000 replicates in the Bayesian inference analysis.

\section{RESULTS}

A single infection was found in Nassarius olivaceus. There was no evidence of infection by a zoogonid in either N. dorsatus or N. pullus.

\section{Morphological data - intramolluscan and free-living stages}

\section{Cercaria capricornia XI}

Fig. 1

Description: Sporocyst (Fig. 1C, based on six unflattened specimens): Body cylindrical with posterior extremity broadly rounded, 225-410 (311) long by 62-110 (85) wide. In reproductive and digestive glands.

Cercaria (Fig. 1A-B, based on eight naturally emerged specimens): Body elliptical, widest point immediately anterior to ventral sucker, 230-295 (264) long by 67-78 (73) wide; length/width 2.96-4.07 (3.63). Tegument spinose; spines arranged in regular rows in forebody, diffuse in hindbody. Oral sucker ventrally subterminal, 35-40 (38) long by 35-43 (39) wide. Stylet absent. Ventral sucker 35-45 (39) long by 35-50 (41) wide. Mouth subterminal, opening anteroventrally. Forebody 125-148 (136) long; forebody/hindbody 0.93-1.00 (0.96). Pharynx 20-22.5 (20.5) long by 15 wide $(n=4)$. Penetration glands numerous, difficult to discern. Excretory vesicle thin-walled, saccular, 37-50 (46.5) long by 20-33 (27) wide ( $\mathrm{n}=5)$; excretory pore at posterior extremity. Tail absent.

H o st: Nassarius olivaceus (Bruguière) (Gastropoda, Nassariidae).

L o c a li ty: Cawarral Creek, Keppel Sands, Queensland, Australia $\left(23^{\circ} 19^{\prime} \mathrm{S} ; 150^{\circ} 47^{\prime} \mathrm{E}\right)$

$\mathrm{Habitat}$ : Intertidal mudflats.

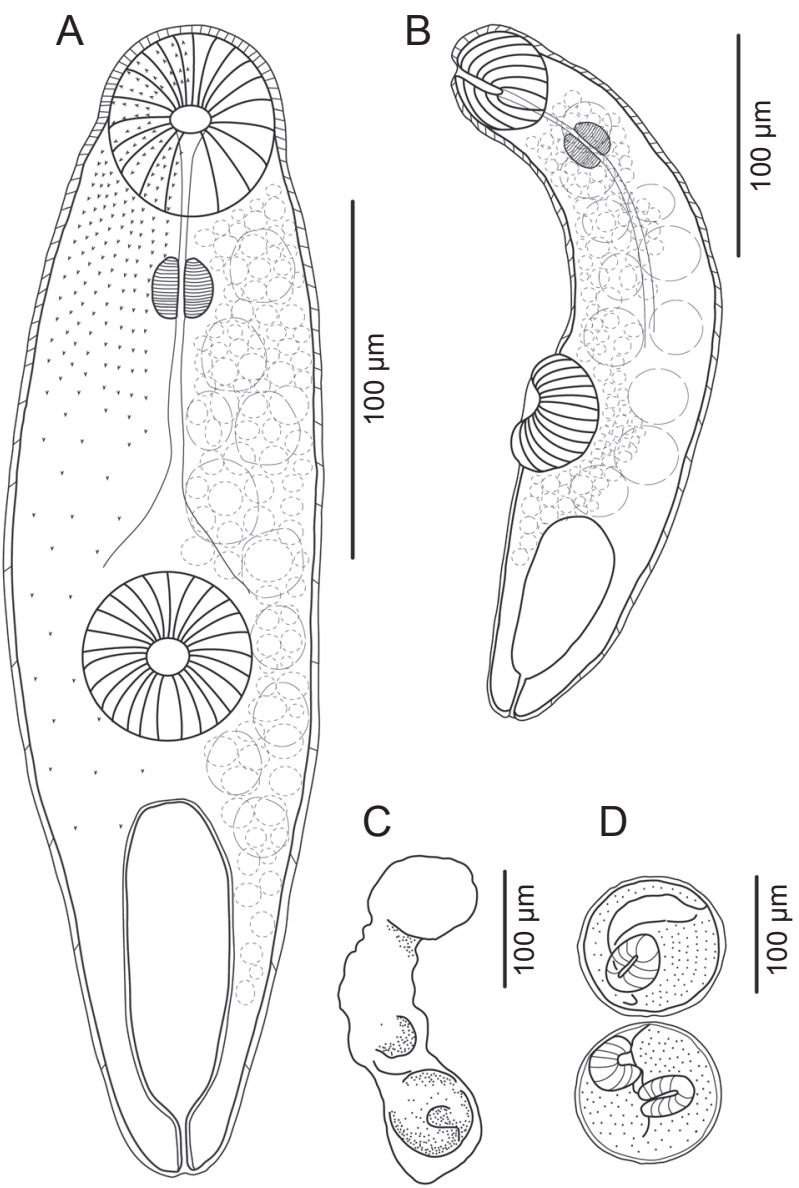

Fig. 1. A,B - Cercaria capricornia XI naturally emerged from Nassarius olivaceus (A - cercaria, heat-killed, ventral view; B - cercaria, heat-killed, from side view); $\mathbf{C}$ - sporocyst, fixed (devoid of cercariae); D - metacercariae.

Location in host (sporocyst): Digestive gland, gonads.

Prevalence of emergence: 0.05\% (1 of 1908 N. olivaceus).

Material deposited: G232091-G232094.

Molecular sequence data: ITS2 ribosomal DNA.

GenBank accession numbers: KJ188132.

Dates of collection: 11 November 2004.

Remarks. The infected gastropod was maintained alive in captivity for 20 weeks following first recognition that it was infected. Large numbers of cercariae emerged daily for a period of 3 weeks followed by a pause of 3.5 weeks during which no or very few cercariae emerged, followed by a further period of heavy emergence for at least 3 further weeks. Cercariae generally emerged before 8 AM each day. Naturally emerged cercariae crawled on the substrate using the oral and ventral suckers. Encysted metacercariae were also recovered from the same cavity block containing motile cercariae (Fig. 1D).

Molecular data - Bayesian inference analysis of ITS2 rDNA: The ITS2 rDNA region sequenced for $C$. capricor- 


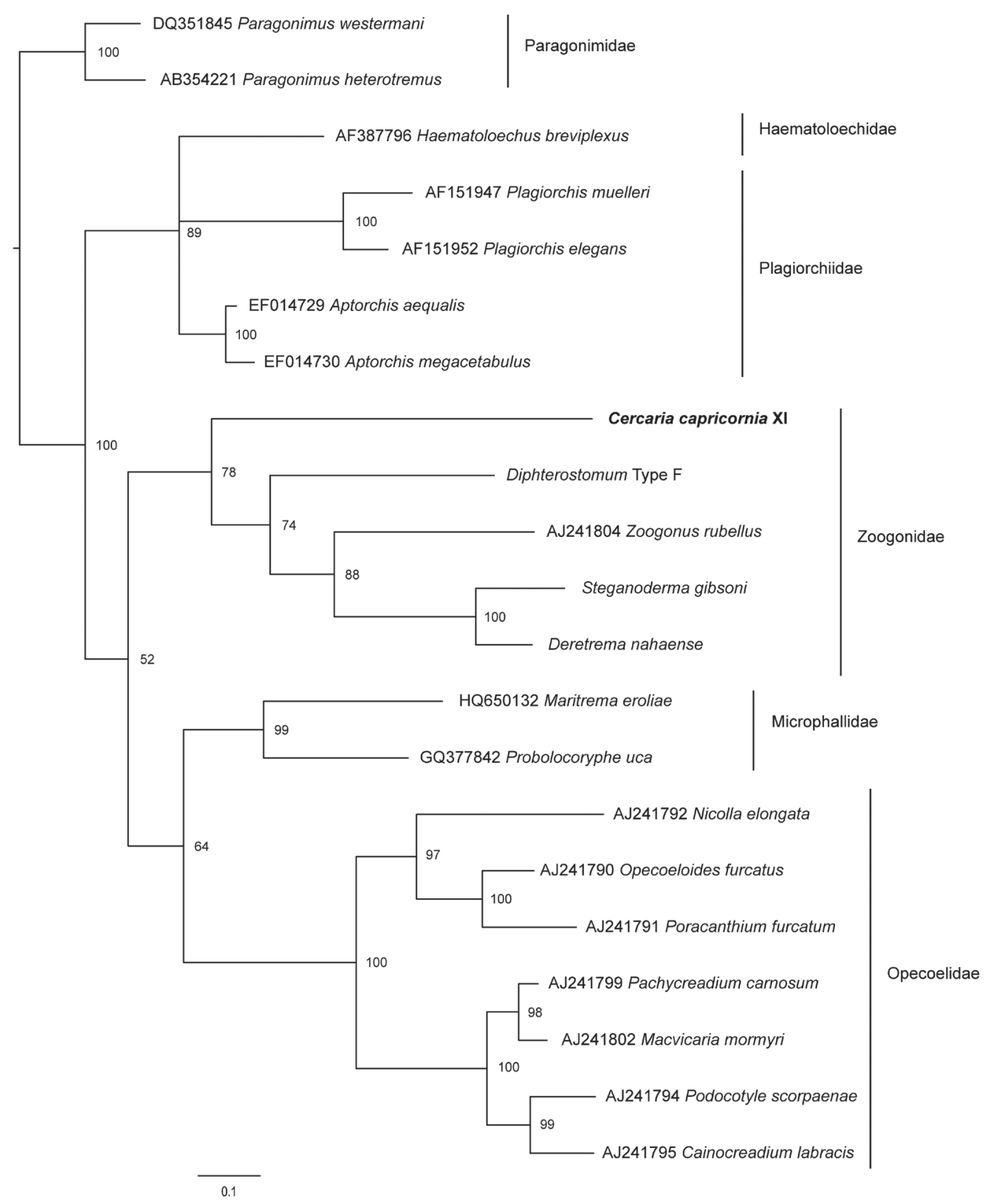

Fig. 2. Bayesian inference analysis of ITS $2(\mathrm{GTR}+\mathrm{G})$ and the relationship between Cercaria capricornia XI and other taxa examined. Posterior probabilities are shown at the nodes.

nia XI was 621 nucleotides long and contained an ITS2 region of 449 nucleotides. Alignment of the ITS2 data for C. capricornia XI and the remainder of the taxa examined yielded 519 characters for analysis. Bayesian inference analysis of the ITS2 dataset resulted in a phylogram with C. capricornia XI forming a clade with, and sister to, the other four zoogonids examined (Deretrema nahaense Yamaguti, 1942, Steganoderma gibsoni Cribb, Bray et Barker, 1992, Diphterostomum Type F and Zoogonus rubellus) (Fig. 2). All of the trematode families included in this analysis were resolved with relatively strong support; the only exceptions were the Haematoloechidae and Plagiorchiidae.

\section{DISCUSSION}

\section{Systematics}

The combination of morphological and molecular analysis suggests that Cercaria capricornia XI belongs to the Zoogonidae, despite the absence of a stylet. This cercaria is similar to other described zoogonid cercariae but can be differentiated on the basis of morphometric data and by the absence of a stylet (Table 2). The cercaria of Zoogonoides viviparus (Olsson, 1868) as described by both Køie (1976) and Lebour (1918) has a stylet, a larger overall body size and larger oral and ventral suckers than C. capricornia XI. Cercaria zoogonides is smaller 
than the other cercariae described as Z. viviparus, but has a similar ovoid shape. Cercaria zoogonides was figured without a stylet, although it appears that the cercaria was described from specimens contained within sporocysts rather than from emerged cercariae and thus may have been immature (Chubrik 1966).

Although $C$. zoogonides has a similar body length to that of $C$. capricornia XI, the body is wider and the oral and ventral suckers are larger. The brief description of C. crispata also omitted mention of a stylet. This species was later synonymised with Diphterostomum brusinae (Stossich, 1888), which has a stylet (Pelseneer 1906). No measurements were provided for $C$. crispata, but the cercaria was figured with a bifurcated excretory vesicle and the ventral sucker was relatively smaller and positioned more posterior than in C. capricornia XI. Similarly, the brief description of $C$. giardi omitted mention of a stylet and did not contain any measurements. Cercaria giardi was figured with the ventral sucker larger than the oral sucker, unlike the oral and ventral suckers of $C$. capricornia XI, which are roughly equal.

The body of Cercaria bulliae Brown et Webb, 1994 is much longer and narrower than $C$. capricornia XI and Cercaria hapax Brown et Webb, 1994 had a distinctive tail holdfast, unlike in this cercaria (Brown and Webb 1994). Cercaria brachycaeca Shimura et Ito, 1980 is smaller than $C$. capricornia XI but has larger oral and ventral suckers (Shimura and Ito 1980). The cercaria of Cercaria kuwaitae IX Abdul-Salaam et Sreelatha, 1998 is smaller, and, although no naturally emerged cercariae were collected and the description was based on the most mature specimens found during dissection, those cercariae can be differentiated from C. capricornia XI by the presence of a stylet (Abdul-Salaam and Sreelatha 1998). The bodies of D. brusinae, C. chilkaensis II and the Diphterostomum sp. from Buccinanops globulosus (Kiener) are wider than that of C. capricornia XI and C. chilkaensis II has larger oral and ventral suckers (Madhavi and Shameem 1991, Gilardoni et al. 2011). The ventral suckers of Zoogonoides laevis Linton, 1940, Z. rubellus and Z. lasius (Leidy, 1891) are also larger than those of $C$. capricornia XI (Linton 1915, Miller and Northup 1926, Stunkard 1932, 1938, 1943). Cercaria A of Wardle (1993) was described as being aspinose anteriorly, whereas C. capricornia XI is spinose over the entire body (Wardle 1993). Cercaria capricornia XI has a general body shape similar to that of D. brusinae, C. chilkaensis II (suggested to be congeneric with D. brusinae) and Z. rubellus.

Cercaria capricornia XI can also be differentiated from $Z$. rubellus based on the nucleotide differences (38\% divergence) over the ITS2 rDNA dataset (Fig. 2). The zoogonid genus to which this cercaria belongs cannot yet be ascertained as there are insufficient taxa for comparison. The ITS2 rDNA region was chosen for these analyses based on the availability of comparative
ITS2 data from the adults of three species of Zoogonidae produced in independent, but as yet unpublished studies, associated with the surveys of Great Barrier Reef and Northern Australian trematode fauna in the laboratory of T. Cribb. Unfortunately, the original specimens and DNA from which the ITS2 sequences were generated were unavailable, so additional markers (e.g. the more conserved and phylogenetically informative small or large subunit nuclear ribosomal DNA regions $18 \mathrm{~S}$ and $28 \mathrm{~S}$ ) could not be sequenced for comparative purposes. While the ITS2 region is not a robust marker for deep-level phylogenetic inference, the combination of morphology, ecology and genetics suggests strongly that this cercaria belongs in the Zoogonidae. The specific identity of this cercaria remains elusive until the adult of this taxon is recovered, the DNA sequenced and a match based on ITS2 or another robust species-level DNA marker made. Deretrema Linton, 1910 and Steganoderma Stafford, 1904 are both in the subfamily Lepidophyllinae Stossich, 1903 and are sister genera in the phylogram, whereas Zoogonus Looss, 1901 and Diphterostomum Stossich, 1903 are both in the subfamily Zoogoninae Odhner, 1902.

This is not the first zoogonid cercaria to be noted to encyst outside a host. Palombi (1930) reported sporocysts in Nassarius mutabilis (Linnaeus) containing encysted metacercariae of D. brusinae and also described the process of encystment of the emerged cercaria in seawater. He suggested two possible transmission strategies: 1) the cercariae encyst within the sporocyst and are then dispersed into the environment when the sporocyst is ruptured, and 2 ) the cercariae emerge and encyst on fauna or flora in the environment where they are ingested by the second intermediate host. Studies on the life cycle of D. brusinae indicated a number of transmission strategies including encystment within sporocysts in the first host, encystment of metacercariae outside sporocysts but remaining within the first host, and cercarial emergence and infection of a second intermediate host (usually a cockle) (Palombi 1930, Pina et al. 2009).

The external encystment of $Z$. viviparus cercariae under extreme osmotic conditions was also observed (Køie 1969). The absence of penetration glands in C. hapax was suggested to imply encystment and passive ingestion as a transmission strategy (Brown and Webb 1994). Similarly, cysts similar to those of Diphterostomum sp. were reported from $N$. orissaensis during the study of C. chilkaensis II (Madhavi and Shameem 1991). No metacercariae were found encysted inside the single infected gastropod host during dissection to suggest that encystment inside the first intermediate host was used by C. capricornia $\mathrm{XI}$ in addition to external encystment.

\section{First intermediate hosts for Zoogonidae}

There are presently 15 cercariae reported as belonging to the Zoogonidae, including $C$. zoogonides as dis- 
Barnett et al.: New zoogonid cercaria from Australia

Table 2. Morphometric comparison of Cercaria capricornia XI to described zoogonid cercariae. Measurements are given in $\mu \mathrm{m}$.

\begin{tabular}{|c|c|c|c|c|c|}
\hline Cercaria & Body length & Body width & Oral sucker & Ventral sucker & Reference \\
\hline Cercaria capricornia XI & $230-295(264)$ & $67-78(73)$ & $35-40(38) \times 35-43(39)$ & $35-45(39) \times 35-50(41)$ & Present study \\
\hline Cercaria brachycaeca & $191-203(198)$ & $79-89(83)$ & $44-48(46) \times 49-54(52)$ & $48-57(51) \times 56-62(59)$ & Shimura and Ito (1980) \\
\hline Cercaria bulliae & $446-859(689)$ & $49-73(56)$ & - & - & Brown and Webb (1994) \\
\hline Cercaria chilkaensis II & $280-300(290)$ & $80-100(90)$ & $56-60 \times 42-44$ & $56-60(58)$ & Madhavi and Shameem (1991) \\
\hline Cercaria hapax & $200-648(348)$ & $40-162(120$ & - & - & Brown and Webb (1994) \\
\hline Cercaria kuwaitae IX & $145-193(165)$ & $53-68(58)$ & $35-40(36) \times 30-35(32)$ & $40-53(45) \times 40-48(44)$ & Abdul-Salam and Sreelatha (1998) \\
\hline Diphterostomum brusinae & 230 & 100 & 34 & 50 & Palombi (1934) \\
\hline D. brusinae & $257-413(319)$ & $82-135(116)$ & $51-67(56)$ & $81-105(94)$ & Pina et al. (2009) \\
\hline $\begin{array}{l}\text { Diphterostomum sp. } \\
\text { (possible D. brusinae) }\end{array}$ & $263-392(323)$ & $90-160(120)$ & $50-76(63) \times 36-69(50)$ & $\begin{array}{l}54-143(96) \times \\
69-126(106)\end{array}$ & Gilardoni et al. (2011) \\
\hline Zoogonoides laevis & $200-500$ & $60-160$ & $60-65$ & $70-80$ & Stunkard (1943) \\
\hline Zoogonoides viviparus & $330-480$ & - & 60 & 100 & Lebour (1918) \\
\hline Z. viviparus & $370-440$ & $176-190$ & $72-77(75) \times 77-82(80)$ & $\begin{array}{l}105-116(108) \times \\
105-110(107)\end{array}$ & Køie (1976) \\
\hline $\begin{array}{l}\text { Cercaria zoogonides } \\
\text { (possible } Z \text {. viviparus) }\end{array}$ & $250-380$ & $100-150$ & $50-60$ & $50-60$ & Chubrik (1966) \\
\hline $\begin{array}{l}\text { Zoogonus lasius } \\
\text { (Cercaria lintoni) }\end{array}$ & $230-420$ & $84-140$ & $40-50$ & $57-70$ & $\begin{array}{l}\text { Linton (1915), } \\
\text { Miller and Northup (1926) }\end{array}$ \\
\hline Z. lasius & - & - & $43-55$ & $62-75$ & Stunkard (1938) \\
\hline $\begin{array}{l}\text { Zoogonus rubellus } \\
\text { (Cercaria reticulatum) }\end{array}$ & $280-570$ & $75-140$ & $76-85$ & $68-76$ & Stunkard (1932) \\
\hline Cercaria A & $220-315(271)$ & $55-77(66)$ & $35-43(39)$ & $48-61(53)$ & Wardle (1993) \\
\hline
\end{tabular}

tinct from $Z$. viviparus, and retaining C. crispata and the Diphterostomum sp. from B. globulosus as distinct from D. brusinae (Tables 2 and 3). Except for C. brachycaeca and C. kuwaitae IX, which were reported in a turbinid and a trochid, respectively, belonging to the Vetigastropoda, all other zoogonid cercariae have been reported from gastropods in the Neogastropoda (Table 3). The family level identity of $C$. brachycaeca is uncertain. Shimura and Ito (1980) noted that it was different from reported zoogonid cercariae in a number of morphological features, including the shape of the excretory vesicle, intestinal caeca and stylet. They investigated the possibility that C. brachycaeca was the cercaria of Proctoeces ichiharai Shimura et Egusa, 1979, a digenean from the Fellodistomidae that infected the same gastropod as both first and final host, but concluded they were not the same species (Shimura and Ito 1980). Wardle (1993) suggested that C. brachycaeca may eventually be found to be a tail-less opecoelid, due to similarities in the excretory system, cercarial development in elongated sporocysts and the utilisation of a vetigastropod as first intermediate host. However, the later report of $C$. kuwaitae IX, also from a vetigastropod and reportedly similar to C. brachycaeca, D. brusinae and Cercaria A (Abdul-Salam and Sreelatha 1998), suggest that infection of a vetigastropod is not necessarily inconsistent with identity as a zoogonid.

The first intermediate hosts for the rest of the cercariae reported as zoogonids or probable zoogonids include 13 from the families Buccinidae, Columbellidae, Fasciolariidae and Nassariidae (superfamily Buccinoidea) of the Neogastropoda and one from the Naticidae (superfamily Naticoidea). Zoogonoides viviparus and C. zoogonides were reported from buccinids, Z. laevis was reported from a columbellid and Cercaria A from a fasciolariid. All other zoogonid cercariae except $D$. brusinae were reported only from nassariid snails. These included Z. lasius from I. obsoleta (Say) and N. mutabilis, Z. rubellus from Nassarius reticulatus (Linnaeus), C. chilkaensis II from $N$. orissaensis and C. capricornia XI from $N$. olivaceus, whereas $D$. brusinae was reported from the nassariids N. mutabilis, Cyclope pellucida Risso and N. reticulatus, and the naticid Euspira pulchella (Risso). The Diphterostomum sp., which was similar to D. brusinae, was reported from the nassariid B. globulosus. From these records, it appears that the dominant first intermediate host group for zoogonids is buccinoid gastropods, and within that superfamily by far the most frequently infected family is the Nassariidae, which harbours at least 7 species. The species richness of the genus Nassarius Duméril is remarkable at 382 species (Appletans et al. 2013, Bouchet and Gopas 2013) and we predict that further investigation of the parasite fauna of nassariids will potentially yield many more zoogonids.

The report by Palombi (1930) of the naticid E. pulchella as a host of $D$. brusinae may be doubtful. When Palombi (1930) synonymised D. brusinae with C. crispata, he stated that his main concern was the difference in the structure of the excretory vesicle, and that was resolved when he confirmed that the excretory vesicle may appear either saccular or bifurcated. However, the description of C. crispata by Pelseneer (1906) is brief and does not include any measurements. In comparison of the figures for both cercariae, there was no description of a stylet in $C$. crispata and the ventral sucker of C. crispata does not appear to be as large as that of D. brusinae, which was described with 'lips' (Palombi 1930, Pelseneer 1906). The 
Table 3. First intermediate hosts of putative Zoogonidae.

\begin{tabular}{|c|c|c|}
\hline Host species & Parasite species & Reference \\
\hline \multicolumn{3}{|l|}{ Clade Neogastropoda } \\
\hline \multicolumn{3}{|l|}{ Superfamily Buccinoidea } \\
\hline \multicolumn{3}{|l|}{ Family Buccinidae } \\
\hline Buccinum undatum Linnaeus & $\begin{array}{l}\text { Zoogonoides viviparus (Olsson, 1868) } \\
\text { [syn. Cercaria capriciosa Cuénot, 1892; Cercaria giardi Pelseneer, } \\
\text { 1906; Zoogonus viviparus (Olsson) by Lebour (1918)] }\end{array}$ & $\begin{array}{l}\text { Pelseneer (1906), } \\
\text { Lebour (1918), } \\
\text { Køie (1976) }\end{array}$ \\
\hline $\begin{array}{l}\text { Buccinum finmarkianum Verkrüzen } \\
\text { [syn. Buccinum finmarchianum } \\
\text { Verkrüzen] }\end{array}$ & $\begin{array}{l}\text { Cercaria zoogonides Chubrik, } 1966 \\
\text { [possible Z. viviparus or Pseudozoogonoides microacetabulum (Shul- } \\
\text { man-Albova, 1952); probable Z. viviparus of Køie 1976] }\end{array}$ & Chubrik (1966) \\
\hline $\begin{array}{l}\text { Colus islandicus }(\mathrm{Mohr}) \\
\text { [syn. Sipho islandicus (Chemnitz)] }\end{array}$ & Cercaria zoogonides Chubrik, 1966 & Chubrik (1966) \\
\hline \multicolumn{3}{|l|}{ Family Columbellidae } \\
\hline $\begin{array}{l}\text { Astyris lunata (Say) } \\
\text { [syn. Mitrella lunata Say] }\end{array}$ & Zoogonoides laevis Linton, 1940 & Stunkard (1943) \\
\hline \multicolumn{3}{|l|}{ Family Fasciolariidae } \\
\hline $\begin{array}{l}\text { Triplofusus giganteus (Kiener) } \\
\text { [syn. Pleuroploca gigantea (Kiener)] }\end{array}$ & Cercaria A of Wardle (1993) & Wardle (1993) \\
\hline \multicolumn{3}{|l|}{ Family Nassariidae } \\
\hline Buccinanops globulosus (Kiener) & Diphterostomum sp. & Gilardoni et al. (2011) \\
\hline \multirow[t]{2}{*}{ Bullia digitalis (Dillwyn) } & $\begin{array}{l}\text { Cercaria hapax Brown et Webb, } 1994 \\
\text { [probable Zoogonoides sp. of Brown and Webb (1994)] }\end{array}$ & Brown and Webb (1994) \\
\hline & Cercaria bulliae Brown et Webb, 1994 (Zoogonidae?) & Brown and Webb (1994) \\
\hline $\begin{array}{l}\text { Cyclope pellucida Risso } \\
\text { [syn. Cyclope donovani (Risso); } \\
\text { Cyclonassa kamyschiensis Chenu] }\end{array}$ & $\begin{array}{l}\text { Diphterostomum brusinae (Stossich, 1888) } \\
\text { [syn. Diphtherostomum brusinae (Stossich, 1888); Distomum brusinae } \\
\text { Stossich, 1888; ?Cercaria crispata Pelseneer, 1906; Cercaria inconstans } \\
\text { Sinitsin, 1911] }\end{array}$ & $\begin{array}{l}\text { Pelseneer (1906), } \\
\text { Sinitzin (1911), } \\
\text { Dolgikh (1970), } \\
\text { Bray (1986) }\end{array}$ \\
\hline $\begin{array}{l}\text { Ilyanassa obsoleta (Say) } \\
\text { [syn. Nassarius obsoletus (Say)] }\end{array}$ & $\begin{array}{l}\text { Zoogonus lasius (Leidy, 1891) Stunkard, } 1940 \\
\text { [syn. Cercaria lintoni Miller et Northup, 1926; Distomum lasium Leidy, } \\
\text { 1891; Zoogonus rubellus (Olsson, 1868) of Stunkard (1938) in part] }\end{array}$ & $\begin{array}{l}\text { Linton (1915), } \\
\text { Miller and Northup (1926), } \\
\text { Shaw (1933), } \\
\text { Stunkard }(1938,1940,1941)\end{array}$ \\
\hline \multirow[t]{2}{*}{ Nassarius mutabilis (Linnaeus) } & Zoogonus lasius (Leidy, 1891) Stunkard, 1940 & Palombi (1930) \\
\hline & Diphterostomum brusinae (Stossich, 1888) & $\begin{array}{l}\text { Palombi (1934), } \\
\text { Bray (1986), } \\
\text { Pina et al. (2009) }\end{array}$ \\
\hline Nassarius olivaceus (Bruguière) & Cercaria capricornia $\mathrm{XI}$ & Present study \\
\hline Nassarius orissaensis (Preston) & Cercaria chilkaensis II Madhavi et Shameem, 1991 & Madhavi and Shameem (1991) \\
\hline \multirow[t]{3}{*}{ Nassarius reticulatus (Linnaeus) } & $\begin{array}{l}\text { Zoogonus rubellus (Olsson, 1868) Odhner, } 1902 \\
\text { (syn. Cercaria reticulatum Stunkard, 1932; Zoogonus mirus Looss, } \\
\text { 1901) }\end{array}$ & $\begin{array}{l}\text { Bray (1986), } \\
\text { Stunkard (1940), } \\
\text { Madhavi and Shameem (1991) }\end{array}$ \\
\hline & Diphterostomum brusinae (Stossich, 1888) & $\begin{array}{l}\text { Dolgikh (1970), } \\
\text { Bray (1986), } \\
\text { Russell-Pinto et al. (2006), } \\
\text { Pina et al. (2009) }\end{array}$ \\
\hline & Unidentified Zoogonidae cercaria & Russell-Pinto et al. (2006) \\
\hline \multicolumn{3}{|l|}{ Superfamily Naticoidea } \\
\hline \multicolumn{3}{|l|}{ Family Naticidae } \\
\hline $\begin{array}{l}\text { Euspira pulchella } \text { (Risso) } \\
\text { [syn. Natica alderi Forbes; } \\
\text { Natica poliana (delle Chiaje)] }\end{array}$ & Cercaria crispata Pelseneer, 1906 (?Diphterostomum brusinae) & Pelseneer (1906), Bray (1986) \\
\hline \multicolumn{3}{|l|}{ Clade Vetigastropoda } \\
\hline \multicolumn{3}{|l|}{ Superfamily Trochoidea } \\
\hline \multicolumn{3}{|l|}{ Family Trochidae } \\
\hline Umbonium vestiarum (Linnaeus) & Cercaria kuwaitae IX Abdul-Salam et Sreelatha, 1998 & Abdul-Salam and Sreelatha (1998) \\
\hline \multicolumn{3}{|l|}{ Family Turbinidae } \\
\hline Turbo cornutus (Lightfoot) & Cercaria brachycaeca Shimura et Ito, 1980 & Shimura and Ito (1980) \\
\hline
\end{tabular}

cercaria of $D$. brusinae from $N$. reticulatus was confirmed by molecular comparison to the adult and was morphologically similar to that of Palombi (Pina et al. 2009, Palombi 1930). Madhavi and Shameem (1991) retained C. crispata as a cercaria separate to $D$. brusinae. It is thus quite possible that $C$. crispata may not be synonymous with $D$. brusinae and may be another species of zoogo- nid. If it is a separate species, this would bring the total number of zoogonid cercariae to 15 and simplify and narrow the first intermediate host distribution of $D$. brusinae.

Acknowledgements. We wish to thank Philip Barton for assistance with field collection and observation of snails, and Stephen McKillup, Ruth McKillup, Mary-Anne Jones, Tony Vize and Haylee Weaver for assistance with field collections. 
Abdul-Salam J., Sreelatha B.S. 1998: Studies on cercariae from Kuwait Bay. IX. Description and surface topography of Cercaria kuwaitae IX sp. n. (Digenea: Zoogonidae). J. Helm. Soc. Wash. 65: 141-146.

Appeltans W., Bouchet P., Boxshall G.A., De Broyer C., de Voogd N.J., Gordon D.P., Hoeksema B.W., Horton T., Kennedy M., Mees J., Poore G.C.B., Read G., Stöhr S., Walter T.C., Costello M.J. (Eds.) 2012: World Register of Marine Species. Accessed at http://www.marinespecies.org on 2013-08-05.

Bouchet P., Gofas S. 2013: Nassarius Duméril, 1805. World Register of Marine Species. World Wide Web electronic publication, www.marinespecies.org/aphia.php? $p=$ taxdetails\&id $=138235$, 08/2013.

BRAY R.A. 1986: A revision of the family Zoogonidae Odhner, 1902 (Platyhelminthes: Digenea): introduction and subfamily Zoogoninae. Syst. Parasitol. 9: 3-28.

BraY R.A. 1987: A revision of the family Zoogonidae Odhner, 1902 (Platyhelminthes: Digenea): subfamily Lepidophyllinae and comments on some aspects of biology. Syst. Parasitol. 9: $83-123$.

Bray R.A. 2008: Family Zoogonidae Odhner, 1902. In: D.I. Gibson, A. Jones and R.A. Bray (Eds.), Keys to the Trematoda. Vol. 3. CAB International and Natural History Museum, London, pp. 605-630.

Brown A.C., Webв S.C. 1994: Organisms associated with burrowing whelks of the genus Bullia. S. Afr. J. Zool. 29: 144-151.

Chubrik G.K. 1966: [Fauna and ecology of trematode larvae from molluscs in the Barents and White Seas.] Trudy Murmanskogo Biol. Inst. 10: 78-166. (In Russian.)

Cribi T.H., Anderson G.R., Adlard R.D., Bray R.A. 1998: A DNA-based demonstration of a three-host life-cycle for the Bivesiculidae (Platyhelminthes: Digenea). Int. J. Parasitol. 28: 1791-1795.

Dolgikn A.V. 1970: [On the helminth flora of molluscs from the Caucasian littoral Black Sea.] In: Biology of the Sea. Naukova Dumka, Kiev, pp. 3-28. (In Russian.)

EDDy S. 1998: Profile hidden Markov models. Bioinformatics 14: 755-763.

EDGAR R.C. 2004: MUSCLE: multiple sequence alignment with high accuracy and high throughput. Nucl. Acids Res. 32: 17921797.

Gilardoni C., Etchegoin J., Diaz J.I., Ituarte C., CreMONTE F. 2011: A survey of larval digeneans in the commonest intertidal snails from Northern Patagonian coast, Argentina. Acta Parasitol. 56: 163-179.

JANGOUX M. 1987: Diseases of Echinodermata. II. Agents metazoans (Mesozoa to Bryozoa). Dis. Aquat. Org. 2: 205-234.

Keller A., Schleicher T., Schultz J., Müller T., DanDEKAR T., WOLF M. 2009: 5.8S-28S rRNA interaction and HMM-based ITS2 annotation. Gene 430: 50-57.

Koetschan C., Förster F., Keller A., Schleicher T., Ruderisch B., Schwarz R., Müller T., Wolf M., Schultz J. 2010: The ITS2 Database III-sequences and structures for phylogeny. Nucl. Acids Res. 38: D275-D279.

KøIE M. 1969: On the endoparasites of Buccinum undatum L. with special reference to the trematodes. Ophelia 6: 251-279.

KøIE M. 1976: On the morphology and life-history of Zoogonoides viviparus (Olsson, 1868) Odhner, 1902 (Trematoda, Zoogonidae). Ophelia 15: 1-14.
Lebour M.V. 1918: A trematode larva from Buccinum undatum and notes on trematodes from post-larval fish. J. Mar. Biol. Assoc. U.K. 11: 514-518.

Linton E. 1915: Note on trematode sporocysts and cercariae in marine mollusks of the Woods Hole region. Biol. Bull. 28: 198-209.

Lo C.M., Morgan J.A., Galzin R., Cribb T.H. 2001: Identical digeneans in coral reef fishes from French Polynesia and the Great Barrier Reef (Australia) demonstrated by morphology and molecules. Int. J. Parasitol. 31: 1573-1578.

MAdDison W.P., Maddison D.R. 2007: Mesquite: a modular system for evolutionary analysis. Version 2.74 . http://mesquiteproject.org.

Madhavi R., Shameem U. 1991: Cercaria chilkaensis II, a new zoogonid cercaria from the snail, Nassarius orissaensis, from Chilka Lake, India. J. Helm. Soc. Wash. 58: 31-34.

Miller H.M.J., Northup F.E. 1926: The seasonal infestation of Nassa obsoleta (Say) with larval trematodes. Biol. Bull. 50: 490-508.

Miller M.A., Holder M.T., Vos R., Midford P.E., Liebowitz T., Chan L., Hoover P., Warnow T. 2009: The CIPRES Portals. CIPRES. World Wide Web electronic publication, www.phylo.org/sub sections/portal, 08/2009.

Morgan J.A.T., Blair D. 1995: Nuclear rDNA ITS sequence variation in the trematode genus Echinostoma: an aid to establishing relationships within the 37-collar-spine group. Parasitology 111: 609-615.

Palombi A. 1930: Il ciclo biologico di Diphterostomum brusinae Stossich (Trematode Digenetico: fam. Zoogonidae Odhner) considerazioni sui cicli evolutivi delle specie affini e dei trematodi in generale. Pubbl. Staz. Zool. Napoli 10: 111-149.

Palombi A. 1934: Gli stadi larvali dei Trematodi del Golfo di Napoli. 1. Contributo allo studio della morfologia, biologia e sistematica delle cercarie marine. Pubbl. Staz. Zool. Napoli 14: 51-94.

Pelseneer P. 1906: Trématodes parasites de mollusques marins. Bull. Sc. France Belg. 40: 161-186.

Pina S., Tajdari J., Russell-Pinto F., Rodrigues P. 2009: Morphological and molecular studies on life cycle stages of Diphtherostomum brusinae (Digenea: Zoogonidae) from northern Portugal. J. Helminthol. 83: 321-331.

Posada D. 2008: jModelTest: phylogenetic model averaging. Mol. Biol. Evol. 25: 1253-1256.

RonQuist F., Huelsenbeck J.P. 2003: MRBAYES 3: Bayesian phylogenetic inference under mixed models. Bioinformatics 19: $1572-1574$.

Russell-Pinto F., Goncalves J.F., Bowers E. 2006: Digenean larvae parasitizing Cerastoderma edule (Bivalvia) and Nassarius reticulatus (Gastropoda) from Ria de Aveiro, Portugal. J. Parasitol. 92: 319-332.

Shaw C.R. 1933: Observations on Cercariaeum lintoni Miller and Northup and its metacercarial development. Biol. Bull. 64: 262-275.

Shimura S., Ito J. 1980: Two new cercariae, Cercaria brachycaeca n. sp. and Cercaria misakiana n. sp., from top shells, Batillus cornutus and Marmarostoma stenogyrum, with notes of their effects on the hosts. Jpn. J. Parasitol. 29: 69-76.

Sinitzin D.T. 1911: [Parthenogenetic generation of trematodes and its progeny in molluscs of the Black Sea.] Mem. Acad. Sc., Petersburg, 8th series, 30, 127 pp. (In Russian.) 
STUNKARD H.W. 1932: Some larval trematodes from the coast in the region of Roscoff, Finistère. Parasitology 24: 321-343.

Stunkard H.W. 1938: Distomum lasium Leidy, 1891 (syn. Cercariaeum lintoni Miller and Northup, 1926), the larval stage of Zoogonus rubellus (Olsson, 1868) (syn. Z. mirus Looss, 1901). Biol. Bull. 75: 308-334.

StUnKaRd H.W. 1940: Life history studies and specific determination in the trematode genus Zoogonus. J. Parasitol. 26: 33-34.

STUNKARD H.W. 1941: Specificity and host-relations in the trematode genus Zoogonus. Biol. Bull. 81: 205-214.
STUNKARD H.W. 1943: The morphology and life history of the digenetic trematode, Zoögonoides laevis Linton, 1940. Biol. Bull. 85: 227-237.

Tamura K., Dudley J., Nei M., Kumar S. 2007: MEGA4: Molecular Evolutionary Genetics Analysis (MEGA) software version 4.0 Mol. Biol. Evol. 24: 1596-1599.

WARDLE W.J. 1993: A new zoogonid cercaria (Trematoda: Digenea) from the Florida horse conch, Pleuroploca gigantea, in the northwestern Gulf of Mexico. J. Helm. Soc. Wash. 60: 216-218. 